MS48 Crystallography in art and cultural heritage

Chairs: Alicja Rafalska-Lasocha, Helen Stoeckli-Evans

\section{MS48-O1 MAKING GOLD: Recent Developments and New Perspectives}

\author{
Anke Zürn ${ }^{1}$
}

1. Artist Researcher based in Biel/Bienne, Switzerland

email: zuern@visual-chemistry.net

End 2011 I left the natural science context, to perform artistic research on topics related to materials science independent from scientists' research obligations, as artists' research methods and working goals embrace also the inclusion of emotions, contradictions, ambiguities, incertitudes, and celebrate uniqueness and non-reproducibility. In Basel I will present my ongoing art projects "MAKING GOLD", "AROUND THE LAKES", and "LOOKING FOR NEW DIAMONDS", while providing a short "golden" glance at artistic research as such.

The projects MAKING GOLD and AROUND THE LAKES both embrace natural dyes and historic lake pigments. The lake pigments are manufactured by adding metal salts and eventually also inorganic substrates to dye extracts from different plant species or insects. Generally any complex forming metal ions could be applied to precipitate the lake pigments; I prefer the use of aluminium, iron, calcium, magnesium, and eventually copper containing salts. Common substrates are lime stone, gypsum, alumosilicates, or aluminium oxides and hydroxides. AROUND THE LAKES combines several projects, all of which canvass freshly produced lake pigments literally as coloured "LAKES" on a coated wooden plate, canvas or paper, referring thus to watercolour painting techniques as well as to the visual research experiments published by Friedlieb Ferdinand Runge ${ }^{1)}$. MAKING GOLD involves the production of lake pigments with wet ground mica and uses the glimmer effects of the flake-like particles to also explore emotions evoked by a "golden glamour". LOOKING FOR NEW DIAMONDS refers to model building traditions in crystallography and chemistry, and addresses the impact of sensuous components on the research process itself. All three projects are highly context sensitive and reflect emotional and economic values of materials, limited raw material resources and related luxury goods or materials trade. At the same time all projects investigate practice-based research approaches, trace visual and sensuous components of researching, and explore the unity of production and perception, the intimate relation of the research and working process with its aesthetic experience.

1) Friedlieb Ferdinand Runge, "Der Bildungstrieb der Stoffe: veranschaulicht in selbstständig gewachsenen
Bildern (Fortsetzung der Musterbilder)", 1855, Oranienburg, Selbstverlag.

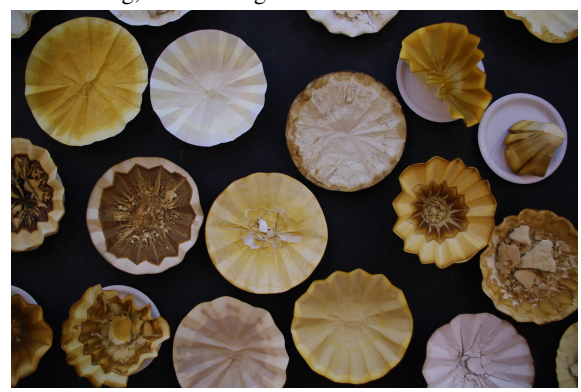

Figure 1. MAKING GOLD: Exhibition view, Anke Zürn, August 2014, Espace Libre, Biel/Bienne, Switzerland.

Keywords: gold, colours, pigments, cultural heritage, art, research 